\section{Flora of Tibet}

$\mathrm{T}$ E plant collection made by Capt. F. KingdonWard in Tibet last year for the British Museum (Natural History) comprises about $\mathbf{7 5 0}$ items, and more than 5,000 specimens. Some 500 species are included. The bulk of the collection was made north of Rima (lat. $28^{\circ} 25^{\prime}$ N., long. $97^{\circ} 0^{\prime}$ E.), in Zayul, south of the great snow range, and in Nagong, north of the snow range. The Nagong plants come from around Shugden Gompa (lat. $29^{\circ} 25^{\prime}$ N., long. $97^{\circ} 0^{\prime}$ E.).

The great range of snow mountains comparable to the Himalaya, and running approximately northwest to south-east, divides this part of Tibet into two. South of this range, in Zayul, the mountains are well wooded with deciduous and evergreen forest. Oaks, maples, birch, hornbeam, magnolias, Ilex and Rhododendron species abound. Higher up there is conifer forest. North of the range, in Nagong, there is no forest and almost the only tree, found in a few favoured localities, is Picea lichiangensis. There is a number of shrubs, especially species of Lonicera, Berberis, Spircea, Rosa, Clematis and Cotoneaster; but chiefly the mountains are covered with a great variety of herbaceous plants. Thus the snow range acts as a rain screen. Amongst the most prominent alpine genera are Gentiana, Primula, Dracocephalum, Cremanthodium, Anemone and Androsace.

One of the principal results of the expedition was the definite recognition and delimitation of three floral zones in Tibet: (1) the desert zone, with very few species of flowering plants ; (2) the outer plateau, with a considerable alpine and a small woody flora; and $(3)$ the river gorge country, divided into $(a)$ upper gorge country with a large alpine flora and a few shrubs and trees, $(b)$ lower gorge country with a wealth of forest. The discovery that the snow range is an eastern extension of the Himalayan range is also important from a phyto-geographical point of view ; as is also the observation that the glaciers on this range formerly extended a long way south. Kingdon-Ward has now been able to trace the southern limit of the ice during the last glacial epoch, from the eastern Himalaya right across to China; this advance of the ice had a profound influence on the flora.

In Nagong, where the snow line stands at about $19,000 \mathrm{ft}$., flowering plants in some variety were found above 18,000 ft.; mastly, however, collections were made at 14,000-16,000 ft. In Nayul, the snow line is lower : most of the plants found in the Rima district were collected between $5,000 \mathrm{ft}$. and $10,000 \mathrm{ft}$., a few alpines at 10,000-15,000 ft. These last include several species of Nomocharis.

One other type of flora requires mention-that of the deep Salween gorge, which was reached in August. The heat was great, the lack of water was conspicuous. A peculiar flora of dwarf spiny or prickly shrubs occurs here (altitude 9,000-11,000 ft.).

The southern country traversed is composed almost entirely of igneous rocks: the northern country almost entirely of sedimentary rocks, including limestones, red sandstone and slate.

On the return journey, the Mishmi Hills were crossed by a new route. This country, being technically a part of Assam, falls within the Indian Empire, and few plants were collected there.

In all, a number of new and little-known plants were found, and the distribution of others, especially as between the Himalaya and Chinese mountains, extended; though the most important results were the recognition of the several floral areas in Tibet, and the proof of the Himalayan extension, with all that it implies in the distribution of plants in south. east Asia. Seed of about 180 species was secured, also a number of photographs of plants in their natural surroundings.

The regions which lie to the west of Shugden Gompa, between the Salween and the Tsangpo, still remain to be explored, before we can get an adequate idea of the flora of the river gorge country.

\section{Locust Control*}

THE outbreak of locusts which began in the Sudan, Adgeria and western Asia in 1926 and reached Kenya two years later, increased in intensity so greatly that it exceeded the powers of local checks and expanded rapidly into an enormous, widespread plague, ranging from Bechuanaland into Persia, India and Turkestan. It is estimated that the damage this caused between 1927 and 1931 exceeds $£ 6,000,000$.

The Government realised the significance and at once formed an organisation, which now appears in the form of the Locust Control Committee of the Economic Advisory Council, with headquarters at the Imperial Institute of Entomology, under the direction of Mr. B. P. Uvarov.

The work quickly became international. Italy suggested a congress in Rome, where war was declared upon the loeust by an alliance of British, Italian and French Governments, which have since been joined by the Belgian, Portuguese and Egyptian. A striking illustration of the world-wide interest in this war is seen in the list of works published during the period in question, which covers no less than 35 pages of the reports and includes papers in such unexpected languages as Chinese, Yiddish and Uzbeg, while there are 166 papers in Russian.

The three species concerned are the desert locust, Schistocerca gregaria, Frosk., no doubt the same that plagued Pharaoh, the tropical form of the migratory locust, Locusta migratoria, L., subsp., migratorioides, $\mathbf{R}$. and F., and finally the red locust, Nomidacris septemfasciata, Serv. The first is confined to the arid belt, and the great forests appear to offer a barrier even to flying swarms. The migratory locust frequents the three types of savannah country, but is stopped by the deserts. Its movements are due to reflexes dependent in temperate regions upon temperature, in hot countries upon humidity. The life-history of the migratory locust in the tropics is different from its cycle in the temperate zone, as the egg stage there is short but the adult long, so it is with the latter that the battle must be joined. Spraying with poison dust from aeroplanes, particularly of the auto-giro type, will probably be the solution, coupled with intelligence work in the home breeding areas, which are being investigated by four British, three French and several Indian entomologists.

With the expansion of agriculture in Africa, the potential damage by locusts becomes vast indeed, but much valuable work has been done, and now that the organisation is in full swing, the outlook is encouraging.

M. B.

* The Locust Outbreak in Africa and Western Asia, 1925-31, and the same for 1932. Surveys prepared by B. P. Uvarov for the Committee on Locust Control of the Economic Advisory Council. (London H.M. Stationery Office, 1933.) 58. and 38 . net respectively. 